\title{
Spirometry reference values in Indigenous Australians: a systematic review
}

\author{
Tamara L Blake ${ }^{1,2}$, Anne B Chang ${ }^{3,4}$, Helen L Petsky', Leanne T Rodwell ${ }^{3}$, Michael G Brown ${ }^{5}$, Debra C Hill ${ }^{6}$, \\ Bruce Thompson ${ }^{7}$, Margaret S McElrea ${ }^{2,3}$
}

$\mathrm{R}$ espiratory illnesses are a significant contributor to the morbidity and mortality of Aboriginal and Torres Strait Islander (Indigenous) Australians across all ages. ${ }^{1,2}$ Previous studies have highlighted the high incidence of respiratory disease in Indigenous Australians. ${ }^{3,4}$ In adults, asthma ${ }^{5}$ and chronic obstructive pulmonary disease (COPD) ${ }^{6}$ are the greatest contributors to the respiratory burden, with Indigenous Australians being 2.4 times more likely than non-Indigenous Australians to require hospitalisation.

Spirometry is the most common test ${ }^{8}$ used to aid the diagnosis and management of respiratory diseases. As with all clinical tests, there are standards for performance and interpretation of results. ${ }^{8,9}$ The latter requires comparing the patient's spirometry values (forced expiratory volume in 1 second $\left[\mathrm{FEV}_{1}\right]$ and forced vital capacity [FVC]) against reference values obtained from a representative "healthy" population matched for age, sex, height and ethnicity., The American Thoracic Society (ATS $)^{10}$ and European Respiratory Society (ERS) ${ }^{11}$ outline criteria for developing spirometry reference values that include recruiting individuals who (i) are lifelong nonsmokers, (ii) are free from current respiratory symptoms or a diagnosed respiratory disease, and (iii) have spirometry performed in accordance with ATS-ERS test criteria. ${ }^{8}$ When validating an existing or new reference set using software developed by the Global Lung Function Initiative (GLI), ${ }^{12}$ it is a requirement to have a minimum of 300 participants who meet these criteria.

Anthropometric measures have a significant influence on spirometry values. While the contribution of (and hence adjustment for) age, height and sex is not controversial, the impact of ethnicity is less well defined. The 2005 ATS-ERS guidelines ${ }^{8}$ recommend using ethnic-specific reference values to interpret spirometry results, but these do not exist for many of the world's ethnic groups. The GLI ${ }^{12}$ recently presented validated spirometry reference values for people of European ancestry and three other ethnic groups. African American and South-East Asian groups were found to have $\mathrm{FEV}_{1}$ and FVC values 10-16\% lower than in people of European ancestry of matching sex, height and age, whereas values in North-East Asians were only $1-4 \%$ lower. Use of the correct reference values is important, as comparison against incorrect reference values could misclassify a person as having normal or abnormal lung function, and thus lead to possible misdiagnosis and either deprivation of necessary interventions or unwarranted overtreatment.

Given the high burden of respiratory disease in Indigenous Australians, the variations in ethnic adjustment factors and the implications for clinical care and outcomes, it is important to know how spirometry values in the Indigenous Australian population compare with those among people of European ancestry. This will inform what reference values or adjustment factors should be used. We undertook a systematic review of published and grey literature to explore community-based studies that reported on spirometry

\section{Abstract}

Objectives: To evaluate published spirometry data for Australian Aboriginal and Torres Strait Islander (Indigenous) peoples to determine (i) whether their ethnicity influenced spirometry results; and (ii) if any reliable spirometry reference values exist for Indigenous Australians.

Study design: Systematic review of published and grey literature.

Data sources: PubMed and Cochrane Library databases, references of included articles and appropriate grey literature. Last searches were conducted in April 2016.

Study selection: We included any study that performed spirometry on healthy Indigenous Australians and compared their results with those from people of European ancestry. Two authors independently screened titles and abstracts and then reviewed potentially relevant full-text articles for possible inclusion. We used PRISMA systematic review reporting methods to collate data.

Data synthesis: Of a possible 125 studies, 18 full-text articles were reviewed, but only nine fulfilled the inclusion criteria. None specified Torres Strait Islander inclusion. All studies reported lower spirometry values (as much as 30\% lower) for Aboriginal people compared with non-Indigenous people. Five studies developed spirometry reference values for Indigenous Australians; however, none adhered to all participant inclusion and exclusion criteria outlined by the American Thoracic Society and European Respiratory Society. Hence, reported results and subsequent reference values may not be a true representation of spirometry values in healthy Indigenous people.

Conclusions: The lower spirometry values reported for Indigenous Australians may be due to study limitations. Furthermore, there are currently no reliable spirometry reference values for Indigenous Australians that adhere to current guidelines. Developing a set of Indigenous Australian reference values will improve the accuracy of test interpretation and aid in the diagnosis of respiratory disease in this population.

in healthy Indigenous Australians. Our objective was to determine whether (i) Aboriginal and Torres Strait Islander ethnicity influenced spirometry results; and (ii) any reliable healthy reference values or equations for spirometry (based on ATS-ERS guidelines) existed for Indigenous Australians.

\section{Methods}

\section{Search strategy}

We identified studies by searching PubMed and Cochrane Library databases with the search text: (spirometry or forced expiratory volume) and (indigenous or native or Aboriginal or Torres Strait Islander) and (lung function or respiratory or pulmonary). The last 
searches were conducted in April 2016. We set no limit on the earliest date of publications to include. Details of the search strategy are outlined in the Appendix. We also searched bibliographies of included studies and key Indigenous Australian health-related websites (grey literature) to identify possible additional studies.

\section{Eligibility criteria}

Studies were included in the review if they: (i) recruited Australian Aboriginal and/or Torres Strait Islander people; (ii) performed spirometry; (iii) compared spirometry results of Indigenous participants with those of other ethnic groups (people of European ancestry or other) or a standard reference range; and (iv) included healthy community members.

Studies were excluded if they: (i) did not include a healthy comparison group; or (ii) were either comment articles or study protocols.

\section{Study selection and data extraction}

Two of us (TB and MM) independently reviewed the search results. We identified potentially relevant studies from titles, abstracts or descriptions, then retrieved the full-text articles for review. We used specified criteria to independently select studies from among the full-text articles for inclusion. It was planned that a third person (A C) would adjudicate any disagreements.

Data extracted from each included study were: study location and population source, number of participants and their age range, participants' medical history and smoking status, equipment used and parameters measured, exclusion criteria, comparison of spirometry results with those of a non-Indigenous population, statistical model used and factors examined. It was also noted whether the studies attempted to develop reference equations from their data. Any objective assessments (eg, chest $\mathrm{x}$-rays and medical examination, skin prick tests, airway hyper-responsiveness [AHR] and white blood cell counts) were also recorded.

We used the most appropriate method to grade the included studies in terms of quality, which was to examine their adherence to current ATS-ERS guidelines for developing or validating reference equations.

\section{Results}

The database search identified 125 potential studies. Of these, 18 full-text publications were obtained for consideration for inclusion. Nine studies were excluded after reviewing the full text, leaving nine articles for inclusion. No further relevant studies were identified through searching bibliographies or the grey literature. Reasons for publication exclusions are shown in Box 1.

\section{Study characteristics}

The characteristics of the nine included studies are shown in Box 2. The studies took place in multiple locations around Australia: Queensland (3/9), Western Australia (3/9), Northern Territory $(2 / 9)$, and both Queensland and the NT (1/9). All participants were recruited from rural and remote communities. Of the nine studies, four involved children and/or adolescents, one study focused solely on adults, and four studies included both children and adults. Overall, the studies recruited individuals aged about 5-85 years, although three of the studies did not record the oldest participant age. Seven of the studies tested participants of Aboriginal descent only, while two studies tested both

\section{PRISMA flow chart of included and excluded articles for systematic review of spirometry data in Indigenous Australians}

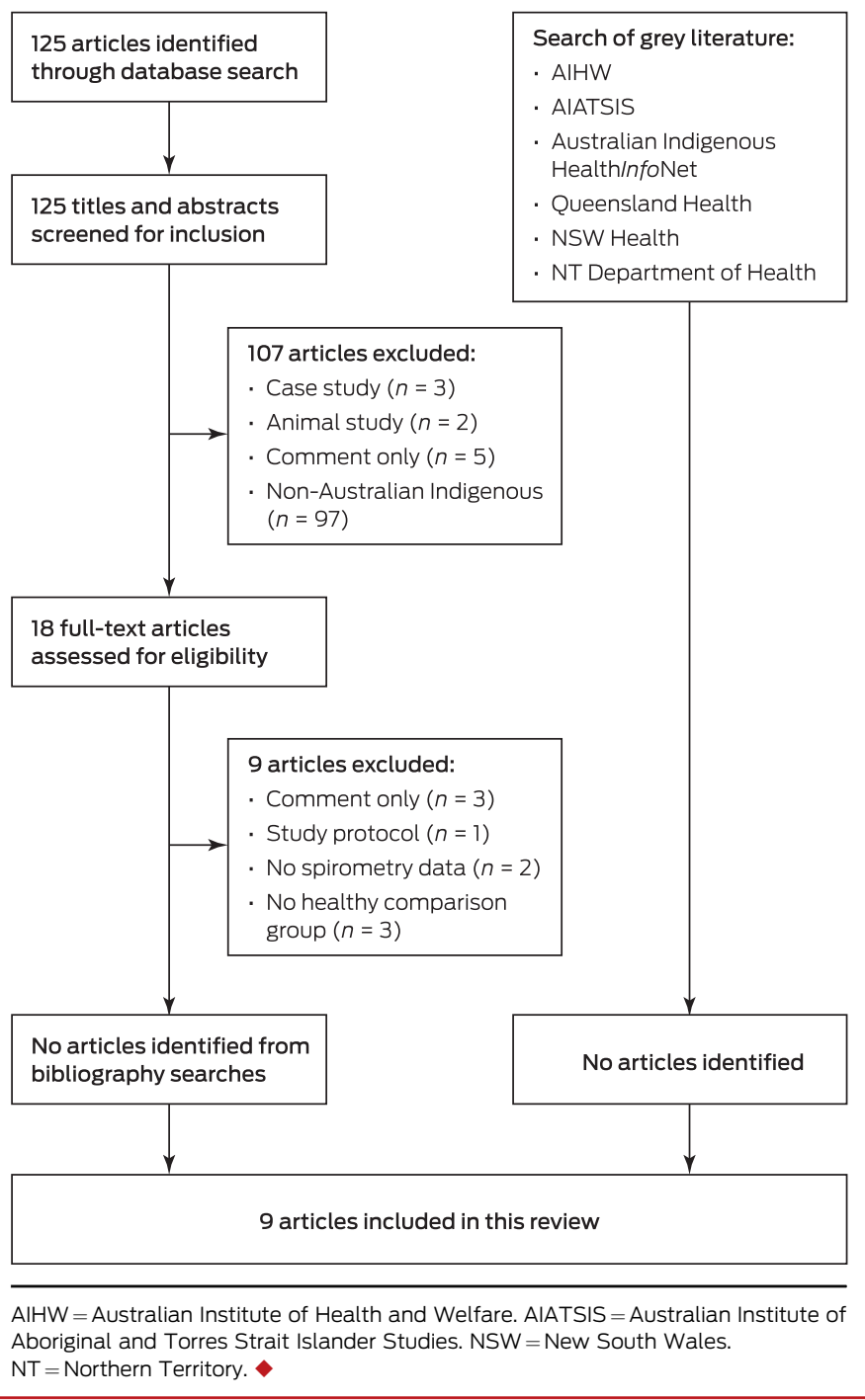

non-Indigenous and Aboriginal Australians. No study stated inclusion of Torres Strait Islander people.

The type and depth of data obtained from the nine studies differed greatly. Atopy was objectively measured in two studies: using the skin prick test in one, and skin prick test and IgE serology in the other. Three studies assessed atopy status during physical examinations and/or by reviewing medical records, while the remaining four did not report any atopy information.

Respiratory history and current health were assessed using questionnaires and/or AHR tests in three studies, questionnaires and chest $x$-ray in one study and questionnaires alone in one study. Five studies reviewed medical charts to obtain previous hospitalisation data, and three studies recorded birth history. Physical examinations were undertaken in two studies. Smoking status was recorded in seven studies, but none used objective measures. Three studies used the British Medical Research Council questionnaire to assess previous and current smoking history. Three studies relied on self-reporting of current smoking status only, while one study asked only about mothers' smoking history during pregnancy (maternal smoking). 
2 Description of the nine included studies

\begin{tabular}{|c|c|c|c|c|c|c|c|c|}
\hline Study, year & Location & Sample size & $\begin{array}{l}\text { Age range } \\
\text { (years) }\end{array}$ & $\begin{array}{l}\text { Medical history and } \\
\text { other data }\end{array}$ & $\begin{array}{c}\text { Smoking status } \\
\text { data }\end{array}$ & $\begin{array}{l}\text { Equipment } \\
\text { used }\end{array}$ & $\begin{array}{l}\text { Exclusion criteria in } \\
\text { publication }\end{array}$ & $\begin{array}{c}\text { Final sample } \\
\text { size }\end{array}$ \\
\hline $\begin{array}{l}\text { Musk et al, } \\
2008\end{array}$ & WA, rural & 251 & $>5$ & $\begin{array}{l}\text { Questionnaire } \\
\text { (respiratory), IgG }\end{array}$ & Questionnaire & Vitalograph & $\begin{array}{l}\text { Unable to perform } \\
\text { test }(n=20)\end{array}$ & 230 \\
\hline $\begin{array}{l}\text { Bucens et al, } \\
2006\end{array}$ & $\begin{array}{l}\text { NT, remote } \\
\text { and rural }\end{array}$ & 547 & $8-14$ & $\begin{array}{l}\text { Physical examination, } \\
\text { medical chart review }\end{array}$ & $\begin{array}{l}\text { Self-reported } \\
\text { (maternal only) }\end{array}$ & Vitalograph & $\begin{array}{l}\text { Unable to perform } \\
\text { test }(n=130)\end{array}$ & 417 \\
\hline $\begin{array}{l}\text { Verheijden } \\
\text { et al, }{ }^{15} 2002\end{array}$ & WA, remote & Not recorded & $>5$ & $\begin{array}{l}\text { Questionnaire } \\
\text { (respiratory), medical } \\
\text { chart review, skin prick } \\
\text { test, AHR, white blood } \\
\text { cell count, IgE }\end{array}$ & Questionnaire & Vitalograph & Nil & 292 \\
\hline $\begin{array}{l}\text { Bremner et al, } \\
1998\end{array}$ & $\begin{array}{l}\text { WA, very } \\
\text { remote }\end{array}$ & 225 & $5-85$ & $\begin{array}{c}\text { Questionnaire } \\
\text { (respiratory), skin prick } \\
\text { test, } \mathrm{AHR}\end{array}$ & Questionnaire & Vitalograph & $\begin{array}{l}\text { Unable to perform } \\
\text { test }(n=18)\end{array}$ & $\begin{array}{c}207(82<18 \\
\text { years, } \\
125 \geq 18 \\
\text { years })\end{array}$ \\
\hline $\begin{array}{l}\text { Veale et al, }{ }^{17} \\
1997\end{array}$ & $\begin{array}{l}\text { Qld and NT, } \\
\text { all rural }\end{array}$ & 1161 & $7-80$ & $\begin{array}{c}\text { Physical examination, } \\
\text { AHR }\end{array}$ & Self-reported & $\begin{array}{l}\text { Mijnhardt } \\
\text { VRS } 2000\end{array}$ & $\begin{array}{l}\text { Loose or chronic } \\
\text { cough, wheeze, } \\
\text { positive AHR, unable } \\
\text { to perform test } \\
(n=134), \text { known } \\
\text { respiratory disease }\end{array}$ & $\begin{array}{c}593(261<20 \\
\text { years, } \\
332 \geq 20 \\
\text { years })\end{array}$ \\
\hline $\begin{array}{l}\text { Thompson } \\
\text { et al, }{ }^{18} 1992\end{array}$ & Qld, rural & 288 & $>20$ & $\begin{array}{c}\text { Questionnaire } \\
\text { (respiratory), medical } \\
\text { chart review, chest } \\
\text { x-ray }\end{array}$ & Self-reported & Vitalograph & $\begin{array}{l}\text { Known respiratory } \\
\text { disease, abnormal } \\
\text { chest } x \text {-ray, loose } \\
\text { cough, unable to } \\
\text { perform test } \\
(n=2),<60 \% \text { lung } \\
\text { function }\end{array}$ & 229 \\
\hline $\begin{array}{l}\text { Watson et al, } \\
1986\end{array}$ & NT, remote & 154 & $11-15$ & Not recorded & Self-reported & Vitalograph & Nil & 151 \\
\hline $\begin{array}{l}\text { Chandler } \\
\text { et } a l,{ }^{20} 1980\end{array}$ & Qld, remote & 92 & $5-13$ & $\begin{array}{c}\text { Medical chart review, } \\
\text { birthweight and } \\
\text { weight at } 1 \text { year }\end{array}$ & Not recorded & Vitalograph & $\begin{array}{l}\text { Unable to perform } \\
\text { test }(n=36)\end{array}$ & 56 \\
\hline $\begin{array}{l}\text { Chandler } \\
\text { et al, }{ }^{21} 1979\end{array}$ & Qld, rural & Not recorded & $5-13$ & $\begin{array}{c}\text { Medical chart review, } \\
\text { birthweight and } \\
\text { weight at } 1 \text { year }\end{array}$ & Not recorded & Vitalograph & Nil & 203 \\
\hline
\end{tabular}

\section{Reported spirometry results}

Comparisons of spirometry values of the Indigenous cohorts with other data are summarised in Box 3. Of the nine studies, only two ${ }^{16,19}$ directly compared results for Indigenous Australian participants with those of non-Indigenous Australians recruited to the study. The remaining seven studies compared results with previously published data; however, two studies ${ }^{13,14}$ did not specify the reference sets used. All the studies reported spirometry values in Indigenous people to be lower than those in people of European ancestry. However, there was a large variation in the differences observed. For example, Chandler and colleagues ${ }^{20}$ noted Indigenous $\mathrm{FEV}_{1}$ and $\mathrm{FVC}$ values to be $\leq 15 \%$ lower, whereas the studies by Verheijden and colleagues ${ }^{15}$ and Veale and colleagues ${ }^{17}$ reported results to be as much as $30 \%$ lower. Musk and colleagues ${ }^{13}$ and Bucens and colleagues ${ }^{14}$ noted that their spirometry results were similar to previous studies and lower than those in people of European ancestry, but did not specify how much lower.

Inconsistencies between the studies in how individuals were excluded from the sample population may have influenced the results. Three studies reported no exclusion criteria (Box 2). Six studies specified exclusion criteria, including not being able to perform the spirometry test. Two studies ${ }^{17,18}$ excluded participants with known or current respiratory symptoms or illnesses, but only Thompson and colleagues ${ }^{18}$ confirmed this by reviewing medical charts. No study excluded participants with current or previous smoking history.

All included studies involved prospective cohort groups and all followed appropriate ATS-ERS criteria when performing spirometry. The aims of the studies differed and included observing lung function, ${ }^{20}$ examining influencing factors ${ }^{13-15}$ and developing reference equations for spirometry in Indigenous Australians $(n=5) \cdot{ }^{16-19,21}$ None of the included studies followed all the ATS-ERS and GLI criteria needed to develop reference equations or validate the spirometry results (Box 4). Only two studies $^{14,17}$ recruited more than 300 participants, the minimum number required to validate new reference values for an ethnic population, according to GLI criteria. ${ }^{12}$

\section{Discussion}

To our knowledge, this is the first systematic review to critically examine studies that have measured spirometry values in Indigenous Australians, and to evaluate the validity of the reference values used or reference equations developed. All included studies reported lower spirometry values $(15-30 \%$ lower) in Indigenous Australians compared with people of European ancestry. No study indicated having any Torres Strait Islander participants. The reported differences seen in these studies are 
3 Comparison of spirometry results between Indigenous Australians and people of European ancestry

\begin{tabular}{|c|c|c|c|c|}
\hline Study, year & $\begin{array}{l}\text { Statistical } \\
\text { model }\end{array}$ & $\begin{array}{l}\text { Factors significant to } \\
\text { spirometry results* }\end{array}$ & $\begin{array}{l}\text { Comparison } \\
\text { population data }\end{array}$ & $\begin{array}{l}\text { Observed variatic } \\
\text { (Indigenous Austral } \\
\text { European ancestr }\end{array}$ \\
\hline Musk et $\mathrm{al}^{13} 2008$ & LR & Age, sex, height, weight, smoking & Unknown $^{\dagger}$ & Lower (non-specifi \\
\hline Bucens et $\mathrm{al},{ }^{14} 2006$ & LR & $\begin{array}{c}\text { Age, sex, height, birthweight, } \\
\text { gestational age, non-Aboriginal } \\
\text { ancestry, residence, cough, } \\
\text { hospitalisations for respiratory } \\
\text { illness }\end{array}$ & Unknown ${ }^{\dagger}$ & Lower (non-specifi \\
\hline Verheijden et al,,$^{15} 2002$ & $\begin{array}{l}\chi^{2} \text {, Student } \\
t \text { tests }\end{array}$ & $\begin{array}{l}\text { Respiratory symptoms, white } \\
\text { blood cell count }\end{array}$ & James et $\mathrm{al}^{22 \dagger}$ & $\leq 30 \%$ lower \\
\hline Bremner et al, ${ }^{16} 1998$ & LR, non-LR & $\begin{array}{l}\text { Age, sex, height, race, asthma, } \\
\text { wheezing, cough, atopy, AHR }\end{array}$ & $\begin{array}{l}1020 \text { recruited } \\
\text { participants }\end{array}$ & $\leq 25 \%$ lower \\
\hline Veale et $\mathrm{al},{ }^{17} 1997$ & MLR & Age, sex, height, smoking & Gore et $\mathrm{al}^{23+}$ & $\leq 30 \%$ lower \\
\hline Thompson et al, ${ }^{18} 1992$ & MLR & Age, sex, height, smoking & Gibson et $\mathrm{al}^{24 \dagger}$ & $\leq 25 \%$ lower \\
\hline Watson et al, ${ }^{19} 1986$ & MLR & Age, height, sex & $\begin{array}{l}246 \text { recruited }^{\text {participants }}{ }^{\ddagger}\end{array}$ & $\leq 20 \%$ lower \\
\hline Chandler et al, ${ }^{20} 1980$ & ANOVA & Age, height, weight & Polgar et $\mathrm{al}^{25 \dagger}$ & $\leq 15 \%$ lower \\
\hline Chandler et al, ${ }^{21} 1979$ & MLR & Age, height, weight & Polgar et $\mathrm{al}^{25 \dagger}$ & $\leq 25 \%$ lower \\
\hline
\end{tabular}

$\mathrm{AHR}=$ airway hyper-responsiveness. ANOVA = analysis of variance. $\mathrm{LR}=$ linear regressions. $M L R=$ multiple linear regressions. * Statistically significant. $\dagger$ Published data on people of European ancestry. $¥$ Non-Indigenous participants recruited as part of the study.

even greater than those observed between many other ethnic populations and people of European ancestry. ${ }^{12,26-30}$ However, as none of the studies adhered to the current ATS-ERS and GLI guidelines for spirometry reference data collection in healthy populations, it remains unknown if the reported lower levels reflect the true healthy reference range for Indigenous Australians. Application of the results from these studies to reference values in the clinical setting is therefore not appropriate, and further studies

4 Suitability of Indigenous spirometry data for developing healthy reference values, according to current ATS-ERS and GLI criteria

\begin{tabular}{|c|c|c|c|c|c|}
\hline \multirow[b]{2}{*}{ Study, year } & \multirow[b]{2}{*}{ Study aim } & \multicolumn{3}{|c|}{ ATS-ERS and GLI criteria } & \multirow[b]{2}{*}{$\begin{array}{l}\text { Validated according } \\
\text { to criteria? }\end{array}$} \\
\hline & & $\begin{array}{l}\text { No smoking } \\
\text { history }\end{array}$ & $\begin{array}{c}\text { No respiratory } \\
\text { history or symptoms }\end{array}$ & $\geq 300$ participants & \\
\hline $\begin{array}{l}\text { Musk et al, } \\
2008\end{array}$ & $\begin{array}{l}\text { Examine influence of } \\
\text { previous infections on lung } \\
\text { function }\end{array}$ & $\times$ & $\times$ & $\times$ & $\times$ \\
\hline $\begin{array}{l}\text { Bucens et al, }{ }^{14} \\
2006\end{array}$ & $\begin{array}{l}\text { Examine influencing factors } \\
\text { on lung function }\end{array}$ & $x$ & $x$ & $\boldsymbol{r}$ & $\times$ \\
\hline $\begin{array}{l}\text { Verheijden et al, } \\
2002\end{array}$ & $\begin{array}{l}\text { Examine differences in } \\
\text { respiratory health between } \\
\text { two communities }\end{array}$ & $x$ & $x$ & $\times$ & $\times$ \\
\hline $\begin{array}{l}\text { Bremner et al, }{ }^{16} \\
1998\end{array}$ & $\begin{array}{l}\text { Examine prevalence of } \\
\text { influencing factors on lung } \\
\text { function and compare } \\
\text { against data for people of } \\
\text { European ancestry }\end{array}$ & $\times$ & $x$ & $\times$ & $x$ \\
\hline Veale et al, ${ }^{17} 1997$ & $\begin{array}{l}\text { Develop reference } \\
\text { equations }\end{array}$ & $x$ & $\boldsymbol{\nu}$ & $\boldsymbol{r}$ & $x$ \\
\hline $\begin{array}{l}\text { Thompson } \\
\text { et al, }{ }^{18} 1992\end{array}$ & $\begin{array}{l}\text { Develop reference } \\
\text { equations }\end{array}$ & $x$ & $\boldsymbol{\nu}$ & $x$ & $x$ \\
\hline $\begin{array}{l}\text { Watson et al, } \\
1986\end{array}$ & $\begin{array}{l}\text { Develop reference } \\
\text { equations }\end{array}$ & $\times$ & $x$ & $\times$ & $\times$ \\
\hline $\begin{array}{l}\text { Chandler et al, }{ }^{20} \\
1980\end{array}$ & $\begin{array}{l}\text { Observe lung function in an } \\
\text { Aboriginal community }\end{array}$ & $\times$ & $x$ & $\times$ & $x$ \\
\hline $\begin{array}{l}\text { Chandler et al, }{ }^{21} \\
1979\end{array}$ & $\begin{array}{l}\text { Measure residual lung } \\
\text { damage from childhood } \\
\text { infections and develop } \\
\text { reference equations }\end{array}$ & $\times$ & $x$ & $\times$ & $\times$ \\
\hline
\end{tabular}


are required to develop suitable Indigenous-specific reference values for use in this population.

Validated ethnic-appropriate reference values are essential for correct interpretation of spirometry results, which subsequently influences the diagnosis of disease (eg, COPD) and the severity of disease (eg, asthma). We found five studies ${ }^{16-19,21}$ that developed reference equations for Aboriginal Australians. However, these studies lacked the rigorous exclusion criteria and appropriate participant numbers essential for developing or validating reference values for spirometry. While most studies excluded participants with respiratory symptoms (ie, known respiratory conditions, presence of cough or wheeze), no study also excluded participants who had a history of smoking or evaluated their history adequately. Exclusion of participants who have previously been hospitalised for respiratory infections (especially in childhood) is important as it is well known that these are associated with lower lung function and chronic respiratory diseases such as COPD and bronchiectasis. ${ }^{3,31}$ Furthermore, the sample size of all studies was small, with only two studies ${ }^{14,17}$ recruiting more than 300 participants, the minimum number required by the 2012 GLI guidelines. ${ }^{12}$

Comparison of the reference equations developed in the studies highlights the potential for misinterpreting and misdiagnosing respiratory disease in the Indigenous population (Box 5). For example, in a hypothetical scenario, the reference equation for children generated by Watson and colleagues ${ }^{19}$ predicted $\mathrm{FEV}_{1}$ and FVC values up to $500 \mathrm{~mL}$ greater than those in the other three studies that developed reference equations for children. ${ }^{16,17,21}$ Results for predicted $\mathrm{FEV}_{1}$ and $\mathrm{FVC}$ values were also markedly different between the three studies that developed adult reference equations. Thompson and colleagues ${ }^{18}$ predicted $\mathrm{FEV}_{1}$ and FVC values up to $400 \mathrm{~mL}$ and $300 \mathrm{~mL}$ greater, respectively, than those predicted by Veale and colleagues ${ }^{17}$ and Bremner and colleagues. ${ }^{16}$ The end result of these differences is that some of the reference values developed in these studies would report lung function to be normal, while others would indicate the presence of disease in both children and adults.

The possible reasons given by the studies' authors for the lower spirometry values observed in Indigenous Australians included external factors (ie, asthma, smoking, cough, repeated childhood infections) affecting lung growth during childhood ${ }^{13,14,16}$ and suboptimal environmental conditions causing a faster decline in lung function during adulthood. ${ }^{17,18}$ Differences between participant recruitment sites were considered the primary factor causing variation in spirometry results in Verheijden and colleagues' study, ${ }^{15}$ as they noted lower spirometry values and more prevalent respiratory symptoms in the desert community compared with the tropical community. These factors, as well as access to quality health care, malnutrition, high levels of smoke exposure, premature birth and low birthweight, have been acknowledged in previous studies $^{27,32-34}$ as negatively influencing respiratory health in these populations. However, the differences observed between the studies in terms of the influence of population differences may have been due to study designs (eg, rural and remote recruitment, pathogen testing).

Examining the effect of ethnicity on lung function is complicated by the fact that "ethnicity" often includes other influences such as social and cultural factors, ${ }^{35}$ socio-economic status, ${ }^{36}$ nutritional status (diet trends), ${ }^{33}$ achieved educational level ${ }^{34}$ and genetic factors from diverse backgrounds. ${ }^{37}$ These factors are often difficult to quantify and measure. Unlike age or height, it is not yet known what influence ethnicity has on the development, decline and overall state of lung function in an individual. Also, selfidentified Indigenous Australians are likely to have a range of Indigenous genetic ancestry, which may further affect interpretation of lung function measurements. It is therefore necessary to examine healthy lung function results from both Aboriginal and Torres Strait Islander populations. Comparison of results between the two populations will determine if a single Indigenous reference equation is clinically appropriate or if two ethnic-specific equations are needed.

All the studies included in this review have important shortcomings that limit the reported findings. In previous studies conducted by members of our group using unadjusted values for spirometry, Indigenous children with lung disease (specifically asthma ${ }^{38}$ and bronchiectasis ${ }^{39}$ ) often had results within the healthy range for people of European ancestry. For example, the mean $\mathrm{FEV}_{1}$ and FVC values in the asthma study were $95 \%$ predicted (SD, $18 \%$ ) and $100 \%$ predicted (SD, $17 \%$ ), respectively. ${ }^{38}$ It is possible that a study that includes only healthy Indigenous Australians (strictly defined and with careful examination of medical history) will find spirometry reference values for Indigenous Australians similar to those for people of European ancestry, or requiring only a small adjustment factor.

Our systematic review also has some limitations. It was restricted to only nine studies, and the differences between the studies in terms of methods and reporting of results affected our ability to make direct comparisons between them.

In conclusion, Indigenous Australians may have a healthy lung function range that differs from that in people of European ancestry,

5 Interpretation of lung function results using five different reference equations

Child scenario: 12-year-old boy, $145 \mathrm{~cm}$ tall, achieved $\mathrm{FEV}_{1}=1.85 \mathrm{~L}$

Adult scenario: 25-year-old man, $170 \mathrm{~cm}$ tall, achieved $\mathrm{FEV}_{1}=2.70 \mathrm{~L}$

\begin{tabular}{|c|c|c|c|c|}
\hline \multirow[b]{2}{*}{ Study, year } & & \\
\hline & Predicted $\mathrm{FEV}_{1}$ & $\%$ predicted, interpretation* & Predicted $\mathrm{FEV}_{1}$ & $\%$ predicted, interpretation* \\
\hline Bremner et $\mathrm{all}^{16} 1998$ & $2.21 \mathrm{~L}$ & $\begin{array}{c}84 \% \\
\text { borderline }\end{array}$ & $3.11 \mathrm{~L}$ & $\begin{array}{c}86 \% \\
\text { normal }\end{array}$ \\
\hline Veale et $\mathrm{all}^{17} 1997$ & $2.02 \mathrm{~L}$ & $\begin{array}{c}92 \% \\
\text { normal }\end{array}$ & $2.97 \mathrm{~L}$ & $\begin{array}{c}91 \% \\
\text { normal }\end{array}$ \\
\hline Thompson et al, ${ }^{18} 1992$ & na & na & $3.40 \mathrm{~L}$ & $\begin{array}{c}79 \% \\
\text { low - disease }\end{array}$ \\
\hline Watson et al, ${ }^{19} 1986$ & $2.57 \mathrm{~L}$ & $72 \%{ }^{\dagger}$ & na & na \\
\hline Chandler et al,,27 1979 & $2.00 \mathrm{~L}$ & $93 \%{ }^{\dagger}$ & na & na \\
\hline
\end{tabular}

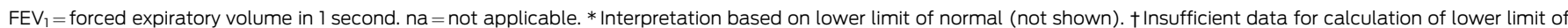
normal. 
and ethnic-specific spirometry reference values should be investigated according to strict guidelines to ensure proper clinical applicability. While our systematic review found lower lung function values in Indigenous Australians compared with people of European ancestry, there were limitations in all the studies. None of the studies provided a reliable set of Aboriginal or Torres Strait Islander spirometry reference values that could be validated against ATS-ERS criteria. It therefore remains inconclusive as to what spirometry reference values should be used when testing Indigenous Australians. Given the importance of spirometry testing on respiratory diagnosis and treatment, there is an urgent need for accurate and validated reference values for Indigenous Australians. The inappropriate use of reference values developed for people of European ancestry could lead to a false-positive or false-negative diagnosis, subsequently affecting treatment and disease progression. Developing a set of Indigenous Australian-specific reference values for spirometry, according to current guidelines, will improve the accuracy of test interpretation, aid in diagnosis and clinical care and reduce morbidity from respiratory disease. Until these reference values are known, health care professionals should be aware of the limitations of using an ethnic correction or adjustment factor when managing Indigenous patients.

Acknowledgements: The Indigenous Respiratory Outreach Care Program received funding under the Queensland Aboriginal and Torres Strait Islander Health Investment Strategy for this work, through the Queensland Aboriginal and Torres Strait Islander Health Unit of Queensland Health. Anne Chang is supported by a National Health and Medical Research Council Practitioner Fellowship (1058213)

\section{Competing interests: No relevant disclosures.}

Provenance: Not commissioned; externally peer reviewed. $\mathbf{~}$

(C) 2016 AMPCo Pty Ltd. Produced with Elsevier B.V. All rights reserved.
1 Indigenous Information Strategy Team, Health Statistics Centre, Queensland Health. Experimental life tables by remoteness, Queensland, 2002-04 and 2005-07. Closing the gap between Indigenous and non-Indigenous life expectancy. Discussion paper. Brisbane: Queensland Health, 2012. https://www.health. qld.gov.au/hsu/pdf/other/explifetab0512.pdf (accessed Nov 2014).

2 Closing the Gap: Prime Minister's report. Canberra: Commonwealth of Australia, 2014. https://www.dpmc. gov.au/sites/default/files/publications/closing the gap_2014.pdf (accessed Nov 2014).

3 Chang AB, Marsh RL, Upham JW, et al. Toward making inroads in reducing the disparity of lung health in Australian Indigenous and New Zealand Maori children. Front Pediatr 2015; 3: 9.

4 O'Grady KA, Taylor-Thomson DM, Chang AB, et al. Rates of radiologically confirmed pneumonia as defined by the World Health Organization in Northern Territory Indigenous children. Med J Aust 2010; 192: 592-595. https://www.mja.com.au/journal/2010/192/10/ratesradiologically-confirmed-pneumonia-defined-worldhealth-organization

5 Australian Centre for Asthma Monitoring. Asthma in Australia 2011 (AlHW Cat. No. ACM 22; Asthma Series No. 4). Canberra: AlHW, 2011. http://www.aihw.gov.au/ WorkArea/DownloadAsset.aspx?id=60129544677 (accessed Dec 2014).

6 Australian Institute of Health and Welfare. Coronary heart disease and chronic obstructive pulmonary disease in Indigenous Australians (AlHW Cat. No. IHW 126). Canberra: AlHW, 2014. http://www.aihw.gov.au/ WorkArea/DownloadAsset.aspx?id=60129547713 (accessed Jul 2015)

7 Australian Health Ministers' Advisory Council. Aboriginal and Torres Strait Islander Health Performance Framework 2014 report. Canberra: AHMAC, 2015. https:// www.dpmc.gov.au/sites/default/files/publications/ Aboriginal_and_Torres_Strait_Islander_HPF_2014\%20-0\% 20edited\%2016\%20June2015.pdf (accessed Nov 2015).

8 Miller MR, Hankinson J, Brusasco V, et al. Standardisation of spirometry. Eur Respir J 2005; 26 : 319-338.

9 Pellegrino R, Viegi G, Brusasco V, et al. Interpretative strategies for lung function tests. Eur Respir J 2005; 26: 948-968.

10 American Thoracic Society. Lung function testing: selection of reference values and interpretative strategies. Am Rev Respir Dis 1991; 144: 1202-1218.

11 Stocks J, Quanjer PH. Reference values for residual volume, functional residual capacity and total lung capacity. ATS Workshop on Lung Volume Measurements. Official Statement of The
European Respiratory Society. Eur Respir J 1995; 8 : 492-506.

12 Quanjer PH, Stanojevic S, Cole TJ, et al. Multi-ethnic reference values for spirometry for the 3-95-yr age range: the global lung function 2012 equations. Eur Respir J 2012; 40: 1324-1343.

13 Musk AW, James AL, Palmer LJ, et al. Respiratory infections and lung function in an Australian Aboriginal community. Respirology 2008; 13: 257-262.

14 Bucens IK, Reid A, Sayers SM. Risk factors for reduced lung function in Australian Aboriginal children. J Paediatr Child Health 2006; 42: 452-457.

15 Verheijden MW, Ton A, James AL, et al. Respiratory morbidity and lung function in two Aboriginal communities in Western Australia. Respirology 2002; 7: 247-253.

16 Bremner PR, De Klerk NH, Ryan GF, et al. Respiratory symptoms and lung function in Aborigines from tropical Western Australia. Am J Respir Crit Care Med 1998; 158: 1724-1729.

17 Veale AJ, Peat JK, Salome CM, et al. 'Normal' lung function in rural Australian Aborigines. Aust N Z J Med 1997; 27: 543-549.

18 Thompson JE, Sleigh AC, Passey ME, et al. Ventilatory standards for clinically well Aboriginal adults. Med $J$ Aust 1992; 156: 566-569.

19 Watson DS, Watson RM, Siskind V. Respiratory function in Aboriginal children. Med J Aust 1986; 144 Suppl: S11-S13.

20 Chandler D, Dugdale AE. Respiratory function tests in Aboriginal children on Mornington Island. Med J Aust 1980; 1 (1 Suppl): 10.

21 Chandler D, Dugdale AE. Respiratory function in Aboriginal school children. Med J Aust 1979; 1 (2 Suppl): 10-12.

22 James AL, Knuiman MW, Divitini ML, et al. Associations between white blood cell count, lung function, respiratory illness and mortality: the Busselton Health Study. Eur Respir J 1999; 13: 1115-1119.

23 Gore CJ, Crockett AJ, Pederson DG, et al. Spirometric standards for healthy adult lifetime nonsmokers in Australia. Eur Respir J 1995; 8: 773-782.

24 Gibson J, Gallagher H, Johansen A, Webster I. Lung function in an Australian population: 1. Spirometric standards for non-smoking adults. Med J Aust 1979; 1 : 292-295.

25 Polgar G, Promadhat V. Pulmonary function testing in children: techniques and standards. Philadelphia: Saunders, 1971.

26 Chinn SR, Rona RJ. Height and age adjustments for cross sectional studies of lung function in children aged $6-11$ years. Thorax 1992; 47: 707-714.
27 Johnston ID, Bland JM, Anderson HR. Ethnic variation in respiratory morbidity and lung function in children. Thorax 1987; 42: 542-548.

28 Whittaker AL, Sutton AJ, Beardsmore CS. Are ethnic differences in lung function explained by chest size? Arch Dis Child Fetal Neonatal Ed 2005; 90: F423-F428.

29 Kiefer EM, Hankinson JL, Barr RG. Similar relation of age and height to lung function among Whites, African Americans, and Hispanics. Am J Epidemiol 2011; 173: 376-387.

30 Yang TS, Peat JK, Keena V, et al. A review of the racial differences in the lung function of normal Caucasian, Chinese and Indian subjects. Eur Respir $J$ 1991; 4: 872-880.

31 Tennant PW, Gibson GJ, Parker L, Pearce MS. Childhood respiratory illness and lung function at ages 14 and 50 years: childhood respiratory illness and lung function. Chest 2010; 137: 146-155.

32 Patrick JM, Patel A. Ethnic differences in the growth of lung function in children: a cross-sectional study in inner-city Nottingham. Ann Hum Biol 1986; 13: 307-315.

33 Harik-Khan RI, Muller DC, Wise RA. Racial difference in lung function in African-American and White children: effect of anthropometric, socioeconomic, nutritional, and environmental factors. Am J Epidemiol 2004; 160: 893-900.

34 Van Sickle D, Magzamen S, Mullahy J. Understanding socioeconomic and racial differences in adult lung function. Am J Respir Crit Care Med 2011; 184: 521-527.

35 Harik-Khan RI, Fleg JL, Muller DC, Wise RA. The effect of anthropometric and socioeconomic factors on the racial difference in lung function. Am J Respir Crit Care Med 2001; 164: 1647-1654.

36 Hegewald MJ, Crapo RO. Socioeconomic status and lung function. Chest 2007; 132: 1608-1614.

37 Kumar R, Seibold MA, Aldrich MC, et al. Genetic ancestry in lung-function predictions. N Engl J Med 2010; 363: 321-330.

38 Valery PC, Masters IB, Taylor B, et al. An education intervention for childhood asthma by Aboriginal and Torres Strait Islander health workers: a randomised controlled trial. Med J Aust 2010; 192: 574-579. https:// www.mja.com.au/journal/2010/192/10/educationintervention-childhood-asthma-aboriginal-and-torresstrait-islander

39 Valery PC, Morris PS, Byrnes CA, et al. Long-term azithromycin for Indigenous children with non-cysticfibrosis bronchiectasis or chronic suppurative lung disease (Bronchiectasis Intervention Study): a multicentre, double-blind, randomised controlled trial. Lancet Respir Med 2013; 1: 610-620. 